BISMA

(Bisnis dan Manajemen)
Volume 14, Issue 1, October 2021, 15-26

ISSN 2549-7790 (Online)

ISSN 1979-7192 (Print)

DOI: 10.26740/bisma.v14n1.p15-26

https://journal.unesa.ac.id/index.php/bisma/index

\title{
The influence of corporate governance on firm value: a case study in Indonesian manufacturing industry
}

\author{
Werner R. Murhadi* \\ University of Surabaya, Indonesia
}

\begin{abstract}
This study aims to determine the effect of corporate governance on financial performance and financial performance on dividend policy, then examining the effect of financial performance and dividend policy on firm value. The research approach is quantitative with panel data type. The sample are companies listed in the manufacturing industry on the Indonesia Stock Exchange. This study found that independent commissioners' existence does not affect financial performance. The size of the board of commissioners, audit committee members, and the number of board meetings do not affect financial performance. The study also found that financial performance and free cash flow affect the company's dividend policy. Indeed, the results show that financial performance affects firm value while dividend policy does not affect it. These results have theoretical implications for supporting agency theory. The independent commissioners will reduce conflict and thus improve the financial performance.
\end{abstract}

Keywords: corporate governance; dividends; financial performance; firm value.

Received: December 29, 2020; Accepted: June 3, 2021; Published: October 27, 2021

*Corresponding author

Email:werner@staff.ubaya.ac.id

To cite this document:

Murhadi, W. R. (2021). The influence of corporate governance on corporate value: a case study in Indonesian manufacturing industry. BISMA (Bisnis dan Manajemen), 14(1), 15-26. https://doi.org/10.26740/bisma.v14n1.p15-26.

\section{INTRODUCTION}

Research on corporate governance has been widely carried out in both developed and developing countries (Hadi et al., 2020). It is realized that companies with good governance are believed to protect the interests of shareholders. With good governance, it is expected to minimize investment risk and contribute to financial performance. Many studies notice the governance importance, including in Indonesia (Hadi et al., 2020). However, governance research in Indonesia mostly refers to companies in developed countries, where good governance can directly affect financial performance and firm value. Good corporate governance is also needed in developing countries, so it will reduce investment risk for investors. In Indonesia, good corporate governance can affect the company's financial 
performance, especially profitability (Azaria et al., 2021). High profitability is supported by the availability of sizeable free cash flows, resulting in high dividend payments. Under these conditions, the company's profitability and dividends will have an impact on firm value. Corporate governance does not necessarily directly impact firm value because corporate governance in Indonesia can only be observed through the board of commissioners' statements and other information contained in the annual report. Meanwhile, a few activity reports were provided by companies except dividends and acquisitions policies. An activity report has negligible impacts on public investors until the company publishes the annual report (Asali et al., 2019).

Gordini \& Rancati (2017) stated that corporate governance strongly influences the board and top management's actions to affect financial performance. Corporate governance has attracted much research to examine the relationship between board characteristics and financial performance (Ntim, 2015). Various kinds of good corporate governance measurements including the size of the board of commissioners, the presence of independent commissioners, the existence of the audit committee, and the frequency of board meetings (Michelberger, 2016; Arora \& Sharma, 2016; Charles et al., 2018; Gomez et al., 2018; Kiliç \& Kuzey, 2016; Assenga et al., 2018). This study considers the natural conditions in the Indonesian capital market and and the effect of dividend policy and financial performance on firm value which integrates accounting-based and market-based performance.

\section{The Effect of Board of Commissioners on Financial Performance}

The board of commissioners is seen as an essential mechanism in a company because the board of commissioners is responsible for overseeing and protecting the company's shareholders (Campbell \& Mínguez-Vera, 2008). The board of commissioners plays a fundamental role in strengthening corporate governance by monitoring and providing advice on resource provision (Ntim, 2015). However, Yermack (1996) found that the board of commissioners' size hurt financial performance. The negative relations occur because the smaller the commissioners' size, the better it can communicate and coordinate. Then, the small board size has lower costs and can make decisions more quickly. The negative relation is also supported by Arora \& Sharma (2016) who found that board size harms the company's financial performance. A smaller board size will make it easier to reach an agreement at the time of decision making and will be better due to greater coordination and fewer communication problems. Another argument is that the board of commissioners' size with a smaller number of members is more efficient in controlling management (Randøy et al., 2009). Unlike previous research, Gomez et al. (2018) described that the board of commissioners' size does not affect the company's performance measured through return on assets. There is no influence on the board of commissioners' size on performance because it is not the size of the board of commissioners that will impact performance but the effectiveness of the supervision itself (Yilmaz, 2018; Paniagua et al., 2018). Based on the previous research, the hypothesis of this study is stated as follows:

H1: The board of commissioners has a negative effect on financial performance. 
Murhadi, W. R.

The influence of corporate governance on corporate value: a case study in Indonesian manufacturing industry

\section{The Effect of Independent Commissioners on Financial Performance}

Good corporate governance is also reflected in the presence of independent commissioners. In Indonesia, the existence of an independent commissioner is mandatory as regulated in the company law. The increasing number of independent commissioners can make the commissioners act objectively and protect all company stakeholders. Furthermore, a large board size can provide greater oversight and more effective decision making (Asali et al., 2019). Arora \& Sharma (2016) explain that the independent board of commissioners positively affects the company's financial performance. The independent commissioners in the mainboard are an essential topic in corporate governance because they can affect the board's effectiveness and improve the company's financial performance (Gordini \& Rancati, 2017). However, the research conducted by Gomez et al. (2018) does not show significant impact of independent commissioners toward financial performance. The relationship between independent commissioners and financial performance is not proven because independent commissioners often exist only to fulfil regulations in the capital market in developing countries (Yilmaz, 2018). Based on the previous research, the hypothesis of this study is stated as follows:

$\mathrm{H} 2$ : The independent commissioner has a positive effect on financial performance.

\section{The Effect of Audit Committee on Financial Performance}

One aspect of good corporate governance is the existence of an audit committee. The existence of an audit committee in Indonesia is regulated in the Law No. 40/2007, Article 121 (OJK, 2007). This audit committee is formed by and reports to the board of commissioners. The existence of an audit committee for companies already listed on the stock exchange is mandatory. The audit committee is formed by the board of commissioners with the aim of assisting the supervision of the company.

An audit committee's existence is significant in determining which auditors to use and jointly supervising the company's leading performance indicators. In Indonesia, companies must establish an independent audit committee to oversee and improve the quality of financial reports provided by management to shareholders. The more audit committee members in the company can increase supervision activity to become more effective (Elmagrhi et al., 2017). Adequate supervision will improve the company's performance because management cannot rashly harm the shareholders (Sani \& Musa, 2017). Based on the previous research, the hypothesis of this study is stated as follows:

H3: The audit committee has a positive effect on financial performance.

\section{The Effect of Board of Commissioner's Meetings on Financial Performance}

The following corporate governance aspect is seen through board of commissioners' meetings frequency. The board of commissioners' meetings shows how often the board meets every year (Benjamin \& Zain, 2015). The board of commissioners' meeting frequency as a proxy for improved corporate governance is that more frequent board meetings can increase coordination and effectiveness, thereby giving commissioners more time to supervise or evaluate management performance (Akbar et al., 2016). The positive relations are supported by Elmagrhi et al. (2017) who stated that increasing managerial monitoring activities through board meetings can reduce agency problems and improve financial performance, including dividend payments. However, other studies explained that more and more meetings indicate 
problems in the organization and will decrease performance (Yilmaz, 2018). Based on the previous research, the hypothesis of this study is stated as follows:

H4: Board of commissioner's meetings have a positive effect on financial performance.

\section{The Effect of Financial Performance and Free Cash Flow on Dividends}

After describing the effect of good corporate governance on financial performance, the following model examines the effect of financial performance and free cash flow as control variables on dividends. Good financial performance is reflected in the high profitability and adequate free cash flow within the company. Certainly, those aspects are included in the annual and quarterly financial reports. In Indonesia, it is common for companies to distribute an annual dividend, but not many can distribute dividends on an interim semi-annual basis. Companies with good financial performance will distribute more dividends than those with poor performance (Sani \& Musa, 2017; Ye et al., 2019; Sanan, 2019).

Apart from high profitability, the existence of free cash flow also impacts high dividend payments. With a large amount of free cash flow, management will prefer to distribute dividends rather than reinvestment, especially in a deteriorating economic situation (Chen et al., 2017; Atmoko et al., 2017; Benjamin \& Zain, 2015; Tahir et al., 2020). In comparison, research with different results is obtained by Elmagrhi et al. (2017), where profitability does not significantly affect dividends paid by the company. Based on the previous research, the hypotheses of this study are stated as follows:

H5: Financial performance has a positive effect on dividends.

H6: Free cash flow has a positive effect on dividends.

\section{The Effect of Dividends and Financial Performance on Firm Value}

The company's dividend policy affects firm value, as stated in the bird-in-hand theory. Investors will perceive companies that pay dividends as a signal of good financial performance because they set aside profits for dividend payments (Asali et al., 2019). In Indonesian capital market, dividend payment announcement will be responded by the market with an increase in share prices. The positive relations are consistent with Pandey (2015) statement, which found that dividend policy will impact the market price of the company's stock. Companies that pay dividends today are also seen as balancing the income needs for current shareholders and the company's future investment needs (Odum et al., 2019; Asali et al., 2019). Investors will perceive companies that can pay dividends positively because only healthy companies can pay dividends to their shareholders (Asali et al., 2019).

On the other hand, companies that do not pay dividends will be perceived negatively (Novita et al., 2016). In addition to dividends, announcements of increasing financial performance in annual and quarterly financial reports also impact firm value. Investors will respond to companies with good performance in the form of an increase in share prices - vice versa. Companies with satisfactory performance will be able to grow in the future (Gunawan et al., 2019). Novita et al. (2016) showed that the essential variable influencing stock price is performance measured by earnings per share. It is also consistent with Odum et al. (2019) which found a strong positive effect on a firm value's financial performance. Based on the previous research, the hypotheses of this study are stated as follows:

H7: Financial performance has a positive effect on firm value. 
Murhadi, W. R.

The influence of corporate governance on corporate value: a case study in Indonesian manufacturing industry

H8: Dividends have a positive effect on firm value.

Based on the concept of a framework that explains the relationship between each variable, a research model is developed as shown in Figure 1.

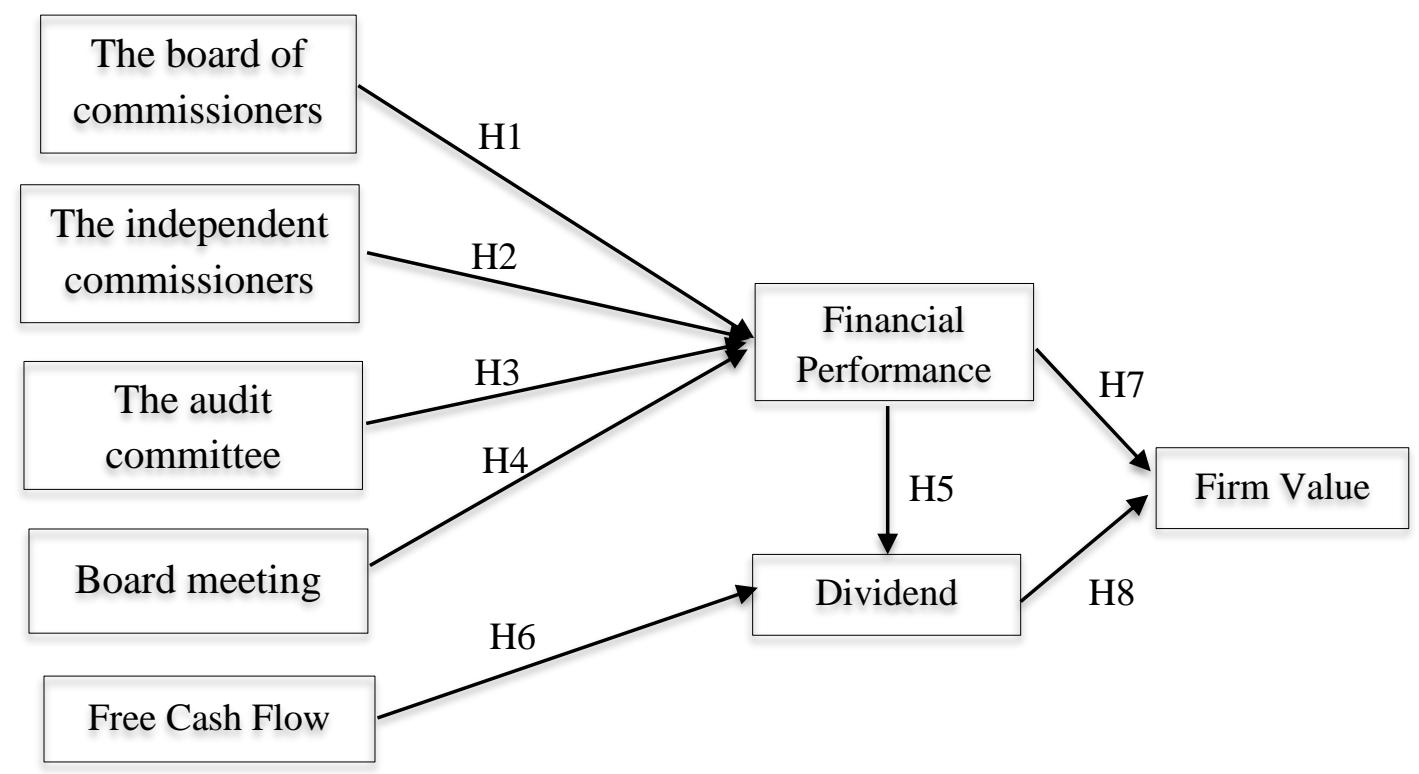

Figure 1. Research Model

\section{METHODS}

This study uses a sample of manufacturing companies listed on the Indonesia Stock Exchange, with the number of observations reaching 435 observations within 2015-2019 data period. Data is obtained from companies that issued financial statements and there is no negative equity. The data used is in the form of panel data where the test is carried out by a classic assumption test and a model suitability test using the Chow and Hausmann test.

Firm value was measured by using Tobin's $Q(\mathrm{Q})$ proxy, financial performance was measured by using a Return On Assets (ROA), and the dividend was measured by using Dividend Payout Ratio (DPR). Meanwhile, corporate governance was measured by the size of the board of commissioners (UDK), the independent commissioner (KI), the size of the audit committee (UKA), the board of commissioners meeting (RDK), and free cash flow (AKB). The size of the board of commissioners was measured by the number of all board of commissioners (non-executive) members. The percentage of independent commissioners measures independent commissioners to the entire board of commissioners. Audit committee members was measured by the number of audit committee members. However, board of commissioners meetings was measured by the number of board meetings. Free cash flow was measured by net operating cash flow divided by total assets.

This study uses company size and debt as control variables. Company size influences financial performance. Large companies obtains economies of scale so their performance can be better than small companies. Another control variable is debt, and companies with large amount of debts impose a financial burden on the company to impact financial performance. The control variable is company size measured using the natural logarithm of Total Assets (TA), while debt is measured by total debt divided by total assets (DR). 
This study uses multiple linear regression with three models. Hypothesis testing model is carried out in three models which can be seen in formula (1), (2), and (3).

$$
\begin{aligned}
& R O A_{i t}=\alpha+\beta_{1} \cdot U D K_{i t}+\beta_{2} \cdot K I_{i t}+\beta_{3} \cdot U K A_{i t}+\beta_{4} \cdot R D K_{i t}+\beta_{5} T A_{i t}+\beta_{6} . D R_{i t}+\varepsilon \ldots . . \\
& D P R_{i t}=\alpha+\beta_{7} \cdot R O A_{i t}+\beta_{8} \cdot A K B_{i t}+\beta_{9} \cdot T A_{i t}+\beta_{10} \cdot D R_{i t}+\varepsilon \\
& Q_{i t}=\alpha+\beta_{11} \cdot D P R_{i t}+\beta_{12} \cdot R O A_{i t}+\beta_{13} \cdot T A_{i t}+\beta_{14} \cdot D R_{i t}+\varepsilon
\end{aligned}
$$

In formula (1), (2), and (3), $R O A_{i t}$ stands for return on asset of firm $\mathrm{i}$ on year $\mathrm{t}$, $U D K_{i t}$ stands for board size of firm i on year t, $K I_{i t}$ stands for independent board of firm $\mathrm{i}$ on year $\mathrm{t}, U K A_{i t}$ stands for Audit committee of firm i on year t, $R D K_{i t}$ stands for the number of the board meeting of firm i on year $\mathrm{t}, T A_{i t}$ stands for total asset of firm $\mathrm{i}$ on year $\mathrm{t}, D R_{i t}$ stands for debt ratio of firm i on year $\mathrm{t}, D P R_{i t}$ stands for dividend payout ratio of firm i on year $\mathrm{t}$, $A K B_{i t}$ stands for free cash flow of firm i on year $\mathrm{t}$, and $Q_{i t}$ stands for Tobin's $\mathrm{Q}$.

\section{RESULTS AND DISCUSSION Result}

After performing the tests and following the assumptions, the results are obtained as follows. Table 1 shows the distribution of manufacturing company data. After conducting the multicollinearity test on each model, there are no variables that are experiencing multicollinearity.

Table 1. Descriptive Statistical Output

\begin{tabular}{lcccc}
\hline \multicolumn{1}{c}{ Variables } & Min. & Max. & Mean & N \\
\hline Q & 0.00 & 11.33 & 1.17 & 435 \\
DPR & 0.00 & 18.66 & 0.39 & 435 \\
AKB & -0.41 & 0.47 & 0.03 & 435 \\
ROA & -0.12 & 0.92 & 0.07 & 435 \\
UDK & 2 & 12 & 4.39 & 435 \\
KI & 0.2 & 0.8 & 0.41 & 435 \\
UKA & 1 & 5 & 3.05 & 435 \\
RDK & 1 & 38 & 7.2 & 435 \\
TA & 11.13 & 14.55 & 12.49 & 435 \\
DR & 0.02 & 0.82 & 0.41 & 435 \\
\hline
\end{tabular}

After carrying out the Chow and Hausmann test for panel data, the best model is presented in Table 2. In table 2, * stands for sig. $\alpha$ at $10 \%$, ** stands for sig. $\alpha$ at $5 \%$, and *** stands for sig. $\alpha$ at $1 \%$. Model 1 shows the results of corporate governance as measured by independent commissioners have a significant effect on financial performance. In contrast, the board of commissioner's size, the existence of the audit committee, and the number of meetings do not have a significant impact on financial performance. Furthermore, only hypothesis 2 is accepted, while hypotheses 1, 3, and 4 are not accepted. These results show that independent commissioners not related to management and the majority shareholder can conduct more effective supervision. Meanwhile, the size of the board of commissioners does not affect performance. This result can be explained by using the company law, namely, the commissioner's decision is single, and so the number of commissioners will not affect the company's performance. This study results in hypothesis 5 that companies that are able to generate high profits will be able to pay bigger dividends. For hypothesis 6 it is also accepted that high free cash flow can be used by the company to invest so that the dividends paid are limited. Hypothesis 7 also shows significant results where companies with high profits will be 
Murhadi, W. R.

The influence of corporate governance on corporate value: a case study in Indonesian manufacturing industry responded to by the market by increasing the company's market value. Hypothesis 8 shows insignificant results where the size of the dividend payment has no effect on firm value

Table 2. Test Results for Three Models

\begin{tabular}{lrrrrrr}
\hline \multirow{2}{*}{ Variables } & \multicolumn{2}{c}{ Model 1 } & \multicolumn{2}{c}{ Model 2 } & \multicolumn{2}{c}{ Model 3 } \\
\cline { 2 - 7 } & \multicolumn{1}{c}{ Beta } & \multicolumn{1}{c}{ t-stat } & \multicolumn{1}{c}{ Beta } & \multicolumn{1}{c}{ t-stat } & \multicolumn{1}{l}{ Beta } & \multicolumn{1}{c}{ t-stat } \\
\hline$\alpha$ & -0.259 & $-2.881^{* * *}$ & -0.281 & -0.248 & -2.423 & $-2.064^{* *}$ \\
UDK & 0.000 & 0.136 & & & & \\
KI & 0.204 & $5.162^{* * *}$ & & & & \\
UKA & -0.015 & -1.534 & & & & \\
RDK & -0.000 & -0.516 & & & & \\
ROA & & & 1.705 & $1.87^{*}$ & 10.106 & $13.438^{* * * *}$ \\
AKB & & & -1.819 & $-2.268^{* *}$ & & \\
DPR & & & & & 0.032 & 0.643 \\
TA & 0.028 & $3.519^{* * *}$ & 0.070 & 0.745 & 0.269 & $2.752^{* * * *}$ \\
DR & -0.124 & $-5.276^{* * *}$ & -0.640 & $-1.729^{*}$ & -1.170 & $-3.079^{* * *}$ \\
Adj. R Squared & & 0.114 & & 0.155 & & 0.349 \\
F Stat & & $10.364^{* * *}$ & & $2.140^{*}$ & & $59.174^{* * *}$ \\
N & & 435 & & 435 & & 435 \\
\hline
\end{tabular}

\section{Discussion}

In the Indonesian corporate system, the commissioner is a supervisory function and provides advice to the board of directors so he or she does not directly impact the financial performance. The results of this study are consistent with previous research from Arora \& Sharma (2016) where there is no relationship between performance and corporate governance. The result shows the negative effect of audit committee towards financial performance. The extensive audit committee's size will impact the company expenses. Higher company expenses will decrease the financial performance. The audit committee does not affect the financial performance. This study is consistent with the findings of Abu et al. (2016). The reason is that the audit committee's function is to carry out audit activities on what the company has done so it does not have a direct impact on the financial performance. Boards of commissioner meetings number has no significant effect towards financial performance. This study consistently supports Naseem et al. (2017) who found similar results. The high frequency of meetings indicates that the decision-making process on the boards of the commissioner is not easy and will reduce the financial performance. This result happens due to the nature of the commissioners, whose function is only to provide advice and supervision, so it does not directly impact operational decisions and the financial performance.

From model one, company size significantly affect financial performance. This positive result is consistent with the findings of Azaria et al. (2021). A large company will achieve economies of scale so the production cost per unit is lower than a smaller company. Achieving the economies of scale will have an impact on the higher financial performance. Furthermore, the debt has a significant negative impact on the financial performance. These negative results support the research of Azaria et al. (2021). Companies with large amount of debts will have enormous financial burdens that negatively affect the financial performance.

In the second model, hypothesis five is accepted. The second model is a continuation of the first model. More specifically, the first model tests the effect of governance on the financial performance, while the second one examines the effect of the financial performance on the dividends paid to shareholders. Table 2 shows that companies with satisfactory performance 
will tend to distribute more enormous dividends. This result follows the signaling theory that only companies with satisfactory performance will be able to distribute dividends. These results also support agency theory, which indicates that if the company performs well, the profits earned can be distributed to shareholders, reducing agency conflicts between management and shareholders.

However, this study also finds different results compared with the previous studies in that the free cash flow has a significant negative effect. This result explains that companies with ample free cash flow do not distribute their dividends more. This finding is consistent with the descriptive statistics in Table 1 regarding the average free cash flow of the company is quite low, but the average dividend distribution is relatively high. This result explains that even though the company does not have a large amount of free cash flow, it still distributes dividends because this is an important aspect to provide a positive signal for shareholders. In the second model, the control variable, firm size, does not affect the dividend policy. One of the reasons why this result appears is because many Indonesian companies tend to use the previous regular dividend policy on the current period. This result implies that the company size does not affect dividend policy because companies tend to pay the same dividend amount in the current period compared with the previous one. The second control variable, debt, has a significant negative result on the dividend policy. This result explains that companies with large amount of debts will have an enormous financial burden, so dividends are much smaller.

The third model tests the effect of performance and dividends on the company value. Financial performance significantly influences the firm value. These results are consistent with the research of Gunawan et al. (2019). This result explains that when a company announces that its performance improves, shareholders' response increases the price. A good financial performance will guarantee long-term business sustainability so that many investors are interested in the companies that have incredible performance. However, this study rejects the following hypothesis, namely the company dividends will impact the high firm value. These results support the research of Husna \& Satria (2019). The dividend policy is expensive because it will reduce future performance if the company distributes dividends. For shareholders, by receiving dividend payments today, the benefits received today will be traded off with a relatively stable stock performance in the future.

Conversely, if the company reduces dividend payments today, shareholders hope that future business growth will be even better. This result impacts the size of dividend payments, but it does not affect the company value. The third model also uses two control variables, namely firm size and debt. Both control variables show significant results. Large companies will be much more attractive to shareholders because the companies will be able to operate economically and reap a bigger market share. Both aspects will have a positive impact on the company's value in the future. For the debt variable, a significant negative result is obtained. This result indicates that the companies with large amount of debts will have high financial burdens, reducing the availability of funds for investment in the future.

\section{CONCLUSIONS}

From the discussed models, it can be concluded that corporate governance, especially the independent commissioners, has a significant effect on the financial performance. Besides, financial performance affects dividend policy and firm value, but dividend policy does not 
The influence of corporate governance on corporate value: a case study in Indonesian manufacturing industry

affect the firm value. These results have theoretical implications for supporting agency theory. The independent commissioners will reduce conflict and thus improve the financial performance. The first model shows the good governance effect on the financial performance, only independent commissioners influence the financial performance. The size of the board of commissioners, audit committee, and the number of meetings do not affect the financial performance. The results of the second model test show that financial performance positively affects dividend policy, but a negative effect of free cash flow can be seen on the dividend policy. In the third model, the result shows that the financial performance hypothesis has a pleasing effect on the firm value while dividend policy does not affect the firm value.

This study has limitations, one of which has a low adjusted $\mathrm{R}$ squared value. Only one hypothesis is accepted from the four hypotheses in model one, namely corporate governance measured by independent commissioners. From the results, future governance research can be conducted by using other proxies such as institutional ownership, managerial ownership, and gender diversity. This study also has limitations in the form of not finding the effect of dividends on firm value. The use of dividend payout can also cause misperception among investors. A low dividend payout ratio does not mean the company has poor performance. A low dividend payout ratio may be due to the company retaining profits for investment in the future.

\section{REFERENCES}

Aanu, O. S., Odianonsen, I. F., \& Foyeke, O. I. (2014). Effectiveness of audit committee and firm financial performance in Nigeria: an empirical analysis. Journal of Accounting and Auditing, 2014, 1-11. https://doi.org/10.5171/2014.301176.

Abu, S. O., Okpeh, A. J., \& Okpe, U. J. (2016). Board characteristics and financial performance of deposit money banks in Nigeria. International Journal of Business and Social Science, 7(9), 159-173. https://doi.org/10.32861/jssr.52.418.423.

Akbar, S., Poletti-Hughes, J., El-Faitouri, R., \& Shah, S. Z. A. (2016). More on the Relationship between Corporate Governance and Firm Performance in the UK: Evidence from the Application of Generalized Method of Moment's Estimation. Research in International Business and Finance, 38, 417-429. https://doi.org/10.1016/j.ribaf.2016.03.009.

Arora, A. \& Sharma, C. (2016). Corporate Governance and Firm Performance in Developing Countries: Evidence from India. Corporate Governance, 16(2), 420436. https://doi.org/10.1108/CG-01-2016-0018.

Asali, F., Murhadi, W. R., \& Sutejo, B. S. (2020, September). The Effect of Corporate Governance and Financial Factors on Dividend Payment. In Contemporary Research on Business and Management: Proceedings of the International Seminar of Contemporary Research on Business and Management (ISCRBM 2019), 27-29 November, 2019, Jakarta, Indonesia (p. 248). CRC Press. Retrieved from https://books.google.com/books?hl=en\&lr=\&id=Yxv9DwAAQBAJ\&oi=fnd\&pg=PA2 $48 \& \mathrm{dq}=$ asali,+murhadi\&ots=7CeE70hX_K\&sig=OM8SwBmZbRCQZA58d2WaoHG9 $18 \mathrm{~g}$. 
Assenga, M.P., Aly, D. \& Hussainey, K. (2018), The Impact of Board Characteristics on the Financial Performance of Tanzanian Firms. Corporate Governance, 18(6), 10891106. https://doi.org/10.1108/CG-09-2016-0174.

Atmoko, Y., Defung, F., \& Tricahyadinata, I. (2017). Pengaruh Return On Assets, Debt to Equity Ratio, dan Firm Size terhadap Dividend Payout Ratio, KINERJA, 14(2), 103-109. http://dx.doi.org/10.29264/jkin.v14i2.2486.

Azaria, D., Murhadi, W. R., \& Sutedjo, B. S. (2021). Board Diversity and Financial Performance in Indonesia. Journal of Entrepreneurship \& Business, 2(2), 86-95. https://doi.org/10.24123/jeb.v2i2.4537.

Benjamin, S. J., \& Zain, M. M. (2015). Corporate Governance and Dividends Payout: Are They Substitutes or Complementary?. Journal of Asia Business Studies, 9(2), 177-194. https://doi.org/10.1108/JABS-08-2014-0062.

Campbell, K., \& Mínguez-Vera, A. (2008). Gender Diversity in the Boardroom and Firm Financial Performance. Journal of Bussines Ethics, 83, 435-451. https://doi.org/10.1007/s10551-007-9630-y.

Charles, A., Dang, R. and Redor, E. (2018), Board Gender Diversity and Firm Financial Performance: A Quantidoi.org/10.1016/j.jcorpfin.2017.01.001le Regression Analysis. International Corporate Governance and Regulation (Advances in Financial Economics), 20, 15-55. https://doi.org/10.1108/S1569-373220180000020002.

Chen, J., Leung, W. S., \& Goergen, M. (2017). The Impact of Board Gender Composition on Dividend Payouts. Journal of Corporate finance, 43, 86-105. https://doi.org/10.1016/j.jcorpfin.2017.01.001.

Elmagrhi, M. H., Ntim, C. G., Crossley, R. M., Malagila, J. K., Fosu, S., \& Vu, T. V. (2017). Corporate Governance and Dividend Payout Policy in UK Listed SMEs. International Journal of Accounting \& Information Management, 25(4), 459-483. https://doi.org/10.1108/IJAIM-02-2017-0020.

Gomez, M. J., Lafuente, E., \& Vaillant, Y., (2018). Gender Diversity in the Board, Women's Leadership and Business Performance. Gender in Management, 33(2), 104-122. https://doi.org/10.1108/GM-05-2017-0058.

Gordini, N., \& Rancati, E. (2017). Gender Diversity in the Italian Boardroom and Firm Financial Performance. Management Research Review. 40(1), 75-94. https://doi.org/10.1108/MRR-02-2016-0039.

Gunawan, K. E., Murhadi, W. R., \& Herlambang, A. (2019). The effect of good corporate governance on dividend policy. In The $16^{\text {th }}$ International Symposium on Management (pp. 57-61). Atlantis Press. https://dx.doi.org/10.2991/insyma-19.2019.15.

Hadi, A. P. K., Murhadi, W. R., \& Sutejo, B. S. (2020). Good corporate governance and agency cost in Indonesia. In Contemporary Research on Business and Management (pp. 358361). CRC Press. https://doi.org/10.1201/9781003035985-84. 
Murhadi, W. R.

The influence of corporate governance on corporate value: a case study in Indonesian manufacturing industry

Husna, A., \& Satria, I. (2019). Effects of return on asset, debt to asset ratio, current ratio, firm size, and dividend payout ratio on firm value. International Journal of Economics and Financial Issues, 9(5), 50-54. https://doi.org/10.32479/ijefi.8595.

Kilic, M., \& Kuzey, C., (2016). The Effect of Board Gender Diversity on Firm Performance: Evidence from Turkey, Gender in Management, 31(7), 434-455. https://doi.org/10.1108/GM-10-2015-0088.

Michelberger, K. (2016). Corporate Governance Effects on Firm Performance: A Literature Review. Regional Formation and Development Studies, 20(3), 84-95. http://dx.doi.org/10.15181/rfds.v20i3.1346.

Naseem, M. A., Xiaoming, S., Riaz, S., \& Rehman, R. U. (2017). Board attributes and financial performance: the evidence from an emerging economy. The journal of developing areas, 51(3), 281-297. https://doi.org/10.1353/jda.2017.0073.

Novita, E., Rahardjo, K., \& Suyadi, I. (2016). The Influence of Financial Performance on Dividend Policy and Its Effect to the Firm Valuation. Profit: Jurnal Administrasi Bisnis, 10(2), 21-32. https://doi.org/10.21776/ub.profit.2016.010.02.3.

Ntim, C. G. (2015). Board Diversity and Organizational Valuation: Unravelling the Effects of Ethnicity and Gender. Journal of Management and Governance, 19(1), 167-195. https://doi.org/10.1007/s10997-013-9283-4.

Odum, A. N., Odum, C. G., Omeziri, R. I., \& Egbunike, C. F. (2019). Impact of Dividend Payout Ratio on the Value of Firm: A Study of Companies Listed on the Nigerian Stock Exchange. Indonesia Journal of Contemporary Management Research, 1(1), 25-34. https://doi.org/10.33455/ijcmr.v1i1.84.

Pandey, I. M. (2015). Financial Management (11th ed.). New Delhi: Vikas Publishing.

Paniagua, J., Rivelees, R., \& Bolufer, J. S. (2018). Corporate Governance and Financial Performance: The role of Ownership and Board Structure. Journal of Business Research, 89, 229-234. https://doi.org/10.1016/j.jbusres.2018.01.060.

Randøy, T., Thomsen, S., \& Oxelheim, L. (2009). A Nordic perspective on corporate board diversity. Oslo: Nordic Innovation Centre.

Sanan, N. K. (2019), Impact of Board Characteristics on Firm Dividends: Evidence from India. Journal of Corporate Governance, 19(6), 1204-1215. https://doi.org/10.1108/CG12-2018-0383.

Sani, A. U., \& Musa, A. (2017). Corporate Board Attributes and Dividend Payout Policy of Listed Deposit Money Banks in Nigeria. International Journal of Research in IT, Management and Engineering, 7(1), 7-13.

Tahir, H., Rahman, M., \& Masri, R. (2020). Do Board Traits Influence Firms' Dividend Payout Policy? Evidence from Malaysia. The Journal of Asian Finance, Economics and Business (JAFEB), 7(3), 87-99. https://doi.org/10.13106/jafeb.2020.vol7.no3.87. 
Undang-Undang Republik Indonesia Nomor 40 Tahun 2007 Tentang Perseroan Terbatas. (2007). Otoritas Jasa Keuangan. Retrieved From https://www.ojk.go.id/sustainablefinance/id/peraturan/undang-undang/Documents/5.\%20UU-402007\%20PERSEROAN\%20TERBATAS.pdf.

Ye, D., Deng, J., Liu, Y., Szewczyk, S. H., \& Chen, X. (2019). Does Board Gender Diversity Increase Dividend Payouts? Analysis of Global Evidence. Journal of Corporate Finance, 58, 1-26. https://doi.org/10.1016/j.jcorpfin.2019.04.002.

Yermack, D. (1996). Higher Market Valuation of Companies with a Small Board of Directors. Journal of Financial Economics, 40(2), 185-211. https://doi.org/10.1016/0304405X(95)00844-5.

Yilmaz, I. (2018). Corporate Governance and Financial Performance Relationship: Case for Oman Companies. Journal of Accounting Finance and Auditing Studies (JAFAS), 4(4), 84-106. https://doi.org/10.32602/jafas.2018.006. 